Teaching Assistant Ionuț JIANU, PhD

The Bucharest University of Economic Studies

E-mail: ionut.jianu@economie.ase.ro

Associate Professor Ioana Andrada GAVRIL, PhD

The Bucharest University of Economic Studies

E-mail: ioana.moldovan@economie.ase.ro

Associate Professor Silvia Elena IACOB, PhD

The Bucharest University of Economic Studies

E-mail: silvia.iacob@economie.ase.ro

Lecturer Andrei HREBENCIUC, PhD

The Bucharest University of Economic Studies

E-mail: andrei.hrebenciuc@economie.ase.ro

\title{
INCOME INEQUALITIES AND THEIR SOCIAL DETERMINANTS: AN ANALYSIS OVER DEVELOPED VS. DEVELOPING EU MEMBER STATES
}

Abstract. This paper assesses the impact of certain social factors on income inequalities in the EU. We applied Panel Estimated Generalized Least Squares method on two clusters, developed vs developing countries. We concluded that the relationship between historical income inequality and its current dimensions is stronger in developing than in developed countries. We also found a higher capacity of social expenditure to reduce income inequality in developed countries, and a positive relationship between unemployment and income inequality in both clusters. Moreover, we identified a positive relationship between tertiary education attainment in developed EU countries, but a negative one in developing countries. Excessive income inequalities affect social and economic dimensions, this being a real issue which can only be addressed at governmental level, by effective and inclusive public policies, which shall be aligned with cultural, social, economic and fiscal features.

Keywords: income, inequality, social determinants, development, Panel.

JEL classification: C33, D63, O11, H55

\section{Introduction}

Income inequalities have long been analysed in the literature, as they represent an important topic regarding ethical resource allocation. Alongside with poverty, income inequalities may have severe social costs. These can lead to political and social instability and can undermine educational progress, which in 
turn affects economic growth (Dabla-Norris et al., 2015), as it undermines human capital accumulation (Galor and Moav, 2004) and skill enhancement.

In the last decades, within country inequalities in the European Union have risen, while nearly all developing Member States, and especially the CEE countries, have registered real convergence, despite the negative influence of the crisis. Inequalities have increased in most developed EU Member States, while having mixed dynamics in the developing ones. Drivers of inequality are numerous and diversified, depending on the level of economic development, public policies, but also on cultural and social factors. In this paper, we analysed the impact of certain social indicators on income inequality depending on the level of development and using Estimated Generalized Least Squares (EGLS) method with fixed effects.

\section{Literature review}

The literature regarding the determinants of income inequality is quite vast, as there are a lot of factors that may affect, directly or indirectly, income inequalities. Generally, the factors impacting inequalities include globalisation, financialization, technological change (Jaumotte et al., 2013), trade and financial openness, economic development, employment, education, skill and capital endowment, labour market features, but also the design of fiscal policy, which may have an important role in the redistribution of income (through social spending and taxes). Moreover, some other factors, such as institutions or the evolution of capitalism, which are quite difficult to assess within statistical data, are considered to have an impact on inequalities.

All these factors may have different effects across countries, depending on the development level, culture, policy design, or different economic features. In this section, we focused on certain social drivers of income inequalities (education, unemployment, and social expenditure) that we will further use as independent variables in our econometric analysis and, in this respect, we summarised the main findings envisaged in the literature.

\section{1. Education and Income Inequalities}

Education is considered a driver of wage gap (Aiyar and Ebeke, 2019). Therefore, quality education available for everyone is considered "a powerful engine" for promoting equality (Walker et al., 2019). In this regard, formal education is considered one of the main factors that influence inequalities, because of its role regarding the access to economic and social opportunities (Cruces et al., 2012). Theoretically, the more unequal the access and opportunities for education, the more unequal the distribution of income in a country is. Especially in the developing countries of the EU, there are regions where access to education is constrained by social and economic factors and, at the same time, the lack of educated and skilled labour further hampers social and economic development, creating a vicious circle against which authorities should act. For advanced

DOI: $10.24818 / 18423264 / 55.2 .21 .08$ 
Income Inequalities and Their Social Determinants: An Analysis over Developed vs. Developing EU Member States

economies, it might be the case that income inequality (and especially poverty) has a stronger impact on educational inequalities, and not the reverse.

The literature presents a series of empirical analyses regarding the relationship between education and inequalities, using several indicators to suggest the skill endowment resulting from education (educational attainment, adult literacy test scores, secondary or tertiary attainment level) or education inequalities and their impact on income inequalities. Generally, the economic literature supports the hypothesis that educational attainment promotes social equality. For instance, De Gregorio and Lee (2002) analysed the relationship between education and income distribution based on a panel dataset for a wide range of countries starting from 1960 to 1990 and conclude that higher educational attainment and distribution of education play an important role in diminishing inequalities.

According to Cruces et al. (2012), "there is vast evidence of a strong positive link between education and earnings at the individual level". The authors find, on average, a positive weak association between education inequality and income inequality for Latin America countries: "countries that experienced a greater reduction in the dispersion of years of education also benefited from a larger reduction in income inequality".

Moreover, other authors analyse the effects of education on income inequality using the differences in the level of educational attainment. In this respect, Cornia (2015) states that the rise in secondary and tertiary completion rates during the 1990 `s and 2000 `s, especially among the poor population, determined, among other factors, a fall in inequality in Latin America, because of a higher skilled labour force and due to a more equal distribution of human capital. On the other hand, Matos (2019) finds that educated and high income households are more likely to be indebted, which proves that tertiary education may increase the inequality through the debt channel.

Recent studies identify inequality of opportunity (which is linked to intergenerational inequality) as the main mediator of the relationship between income inequality and economic growth, which, however has proven difficult to establish (Aiyar and Ebeke, 2019). Aiyar and Ebeke suggest that inequalities in accessing education, labour markets, or financing are the main channels through which the inequality of opportunity affects the relationship between income inequality and economic growth. Intergenerational or social mobility relates to the chances of children of a certain social level to become wealthier than their parents, which is strongly linked to the availability of education (Walker et al., 2019). Looking forward, Aghion et al. (2019) show that innovation is positively correlated with top income inequality, but also positively associated with social mobility. Moreover, education represents a pull factor for migration (Istudor et al., 2020), which in turn may affect inequalities. 
Ionuț Jianu, Ioana Andrada Gavril, Silvia Elena Iacob, Andrei Hrebenciuc

\section{2. Unemployment and Income Inequalities}

Income inequalities and unemployment are highly related. Theoretically, the higher the unemployment rate, the lower the income of population is, which affects income distribution, the poor being mostly exposed. According to Mocan (1995), unemployment worsens the relative situation of the poor, as they are mainly low skilled workers that are at greater risk in the case of economic downturns. On the other hand, Mehic (2018) studies the relationship between industrial employment and income inequality in 27 high and middle income countries from 1991 to 2014 and shows that industrial employment is negatively associated with income inequality.

When analysing the link between unemployment and inequality in Europe, Galbraith et al. (2000) found a positive relationship both within countries and between countries, and through time, and contradict the view that unemployment in Europe is due to some rigidities related to state interventionism (like rigid wages structures, high minimum wages or high social welfare). According to the authors, there was a misleading conventional view that argued for a negative link between unemployment and inequalities, despite the fact that there is evidence that inequalities have always been higher where unemployment rates were higher. Additionaly, some of the rich European countries, which are more equal, tend to register lower unemployment rates, while lower income countries are characterised by higher inequalities, weaker social welfare systems, and higher unemployment.

Apart from diminishing income, unemployment has many other negative effects that are likely to increase inequality even further, such as loss of freedom and social exclusion, skill and motivational loss, psychological harm, gender and racial inequalities, health problems, loss of output, increasing fiscal burdens, and others (Sen, 1997).

Moreover, Stiglitz (2012) considers that the economic and financial crisis of 2008, during which unemployment grew consistently, was a driving force of inequality, given the fact that it affected, to a greater extent, the income level of low-income social classes. Even though, during the crisis, the financial shock was much greater than the shock in the labour market, which also affected the top deciles of the income distribution, the stock market recovered much faster than the labour market. This was due to the structural problems of the labour market, e.g., the incompatibilities between supply and demand. All in all, the revenues of the top deciles recovered much quickly compared to the bottom deciles, which determined the increase in inequality.

\section{3. Social Expenditures and Income Inequalities}

Social expenditures are an important part of government expenditures, which depend on economic growth over the long run (Ayad et. al, 2020). Social expenditures and are an important part of the redistributive policy, which has been subject to extensive debate that is far from end. At a first glance, studying the relationship between disposable income inequality (measured by the Gini index) 
Income Inequalities and Their Social Determinants: An Analysis over Developed vs. Developing EU Member States

and social expenditures of the state might seem redundant, since theoretically social expenditures are redistributive and should have a negative impact on inequalities.

However, Niehues (2010) explains that even though the first round effects of social expenditure tend to have a negative impact on inequality, there are also some second round effects that are deemed to have negative behavioral effects, which translates in a positive impact on inequality. Such cases arise because redistributive policies have a negative impact on the incentives to work and therefore labour supply decreases. Given the fact that the labour supply is more inelastic at higher levels of income, and more elastic for low income levels (Røed. and Strøm, 2002), this would impact especially the low income groups and unemployment at such level would increase, which in turn would have a negative impact on income inequality. However, the biggest part of the social expenditures (which cover both social insurance and social assistance benefits) is allocated to low-income groups, so that the overall impact of social spending on income inequalities would be negative. Niehues (2010) uses a panel regression applying the System GMM estimator and finds that the larger social expenditures are, the lower income inequality is. After analysing the structure of social expenditure, the paper suggests that pensions and unemployment benefits are the ones that foster the decrease in inequality, while more targeted benefits, which have a positive effect on pre-government income inequality, could be weakly, but positively correlated with income inequality.

De Gregorio and Lee (2002) examine whether government social expenditures have any effect on income inequalities and find that they contribute to a more equal distribution of income. According to the results of their regression, an increase of $1 \%$ in the social expenditure to GDP ratio determines a decrease of 0.2 deviation points in Gini coefficient. They explain this impact by two channels: first, they consider that a part of the social expenditure represents transfers to the poorer quintiles, therefore increasing their income (distributional effect), and second, they argue that social expenditures enhance the access of the poor to education and healthcare, which in turn will promote future income equality. In addition, Dabla - Noris et al. (2015) used panel data for a large number of countries (while covering the period 1980-2012) and found that government spending decreases the market and net inequality. However, the effect of social spending on inequalities tends to be higher in countries with inclusive institutions (Dobre et al., 2019).

The methodology we have used follows the conclusion of Molina-Morales et al. (2013), which state that EU Member States are different in terms of their level of economic development, cultural and political beliefs, which influences the efficiency of the social policy. 
Ionuț Jianu, Ioana Andrada Gavril, Silvia Elena Iacob, Andrei Hrebenciuc

\section{Methodology}

This section presents the main methods used for testing the hypotheses we have already set above. First, impact assessment methods are an usefull technique to increase the quality of economic analyses, but in many cases researchers ignore some of the conditions that a model should meet to validate their obtained results. Second, many researchers are influenced by their economic beliefs and use their abilities to direct the results accordingly. To avoid such deficiencies, before starting the estimation of the model, we set the conditions the model should meet (the assumptions of Gauss-Markov theorem) for accepting its statistical validity. However, we will provide a picture in detail of the tests used after describing our approach and the structure of the model.

As we mentioned in the previous section, income inequality is influenced by several factors, but the sign or the magnitude of the coefficients depends on the level of development of the analysed countries. Moreover, given the fact that EU Member States are quite heterogeneous, it is quite difficult to create models and analyses that encompass the cross-country heterogeneity regarding income inequalities. For this reason, many studies focus on national analyses and some present modelling on clusters of countries with certain common features. Given all these, we split European Union 28 Member States in two clusters of 14 Member States each, applying as criterion the median of the gross domestic product per capita expressed in the purchasing power standard, which is frequently used in the scientific economic literature as a relevant indicator for economic development. Further, we estimated the effect of the social drivers of income inequality in the case of both clusters using Panel data over the period 2010-2017, to identify impact differences caused by economic development. The estimation method was chosen in line with the stationarity of the data. We analysed the stationarity of the data using Summary technique which provides a compact view of the results of the following stationarity tests: (i) Levin, Lin \& Chu t*; (ii) Breitung t-stat; (iii) Im, Pesaran and Shin W-stat; (iv) Augmented Dickey-Fuller - Fisher Chi-square; (v) Phillips Perron - Fischer Chi-square.

Lag length was selected using the Schwarz information criterion, which is one of the most used criteria for this process in the scientific literature, given the fact that it is more restrictive than Akaike criterion. In some cases where we met difficulties in the process of assessing the stationarity, we took into consideration the result of Augmented Dickey-Fuller and the graphic representation of the series. Our assessment showed that all selected variables are stationary at the first difference, which demonstrated that VAR or VECM are the most appropriate methods for this estimation, but the last one was rejected by the result of the Johansen Cointegration test. Furthermore, we set the limit of maximum lag to 1 since we worked with yearly data and, a higher lag, combined with a lower number of observations per country could affect the consistency of the estimators. Afterwards, we decided the optimal lag using lag length criteria which summarise

DOI: $10.24818 / 18423264 / 55.2 .21 .08$ 
Income Inequalities and Their Social Determinants: An Analysis over Developed vs. Developing EU Member States

the results of the following tests: LR, Final prediction error, Akaike information criterion, Schwarz information criterion, and Hannan-Quinn information criterion.

However, this paper is limited to analysing the impact of certain social drivers on income inequality in EU Member States. In this respect, we did not analyse this theme using VAR method and we extracted the equation from the vector setting the income inequality as a dependent variable, analysing it separately. In this respect, in the case of each cluster performed, we applied the Estimated Generalized Least Squares (EGLS) method with fixed effects, weighted by Cross-section weights option and White cross-section coefficients covariance method (FGLS) on the following equation:

$$
\begin{gathered}
\operatorname{gini}_{i t}=\alpha_{0}+\alpha_{1} \operatorname{gini}(-1)_{i t}+\alpha_{2} \operatorname{social}(-1)_{i t}+\alpha_{3} \text { tertattaint }(-1)_{i t}+ \\
\alpha_{4} \text { unem }(-1)+\varepsilon_{t}
\end{gathered}
$$

where:

$\alpha_{0}, \ldots, \alpha_{4}$ are the coefficients of the estimators, $\varepsilon_{t}$ is the error term, gini / gini $(-1)$ is the Gini coefficient / Gini coefficient lagged by one year, social $(-1)$ reflects the goverment spending on social protection expressed as a percentage of GDP lagged by one year, tertattaint $(-1)$ is the tertiary educational attainment rate of people aged between 15-64 years lagged by one year and unem $(-1)$ represents the unemployment rate lagged by one year. It worth to be mentioned that all data were extracted from Eurostat database.

We used Fixed Effects Model, since the result of the Redundant Fixed Effects - Likelihood Ratio test indicated that it could provide more consistent estimators than the alternatives - Random Effects Model or a model without effects. In this respect, in the case of each cluster performed, we added 13 dummy variables (number of cross-sections - 1) to the equation 1 to support the estimation of the fixed effects model, as follows:

$\operatorname{gini}_{i t}=\beta_{0}+\beta_{1}$ gini $(-1)_{i t}+\beta_{2} \operatorname{social}(-1)_{i t}+\beta_{3}$ tertattaint $(-1)_{i t}+$

$\beta_{4}$ unem $(-1)_{i t}+o_{1}$ dummy $_{1}+o_{2}$ dummy $_{2}+\ldots+o_{13} d u m m y_{13}+\varepsilon_{t}$

where:

$\beta_{0}, \ldots, \beta_{4}$ are the slopes of the estimators and $o_{1}, \ldots o_{13}$ represents the intercepts of dummy variables.

Fixed Effects Model has two important advantages than its alternatives: (i) it controls the data differences between cross-sections, given that, in many cases, the components of a group register heterogenous developments; (ii) and reduces the uncertainty of the estimators caused by the omitted variable bias issue, which also increases the value of R-squared. However, this approach also has disadvantages, since it cannot assess the impact of a variable with a low groupvariation, but it is not the case of this study. Cross-section weights option and White cross-section covariance were applied to increase the consistency of the 
estimators and to restrict the existence of heteroskedasticity to low dimensions. We had also tried to ex-ante remove its existence, but the application of the Crosssection SUR and Period SUR options were restricted due to the small number of observations and the use of the Fixed Effects Model.

To validate the maximum verisimilitude of the estimators, we used the following tests:

- $\quad$ Fisher test to verify if the model is statistically valid;

- Jarque-Berra test to check if the residuals are normally distributed;

- Breusch-Pagan, Pesaran scaled LM and Pesaran CD to verify the absence of cross-section dependence;

- Klein criterion - to check for the absence of multicollinearity;

- Breusch-Pagan-Godfrey to verify the absence of heteroskedasticity;

- Breusch-Pagan to check if the autocorrelation of residuals does not exist.

In practice, the confirmation of these hypotheses is almost sufficient, but not enough. In this respect, there is one more hypothesis that needs to be verified to confirm that the model is correctly specified, stable and is not affected by a high level of uncertainty. This set the need to use the robustness test, which was performed following the methodology used by Josifidis et al. (2017). Our approach was also aligned with the specifications of the Jacknife Robustness test - which allows performing all possible structured permutations by excluding at least one observation from the data, until all of these have been excluded one time. However, Eviews software does not provide a specific test for robustness, which enforced the need to estimate additional models to check how the results and signs of the coefficients (including standard errors) react when removing one year or one crosssection (country) from the analysis.

Therefore, we have estimated additional 44 models at the level of both clusters ( 8 at the level of each cluster in the case of removing one year from the estimation - 16 in total; 14 at the level of each cluster in the case of removing one country from the estimation - 28 in total), which were used in the process of comparing the results with the baseline model. This approach also checks if the inclusion of some years / countries affects the estimation results.

\section{Results and interpretation}

This section provides the main results of the research. Following the methodology we have used, two clusters of countries were obtained, as can be seen in Figure 1, as follows:

- Developed EU Member States (GDP per capita in PPS > 2017 median 27180): BE, DK, DE, IE, ES, FR, IT, LU, MT, NL, AT, FI, SE, UK.

- Developing EU Member States (GDP per capita in PPS < 2017 median 27180): BG, CZ, EE, EL, HR, CY, LV, LT, HU, PL, PT, RO, SI, SK.

The map also indicates that the level of development in EU is in line with the geographical criterion. In this respect, Eastern European countries belong to the developing EU Member States cluster, while the other cluster is composed by the 
Income Inequalities and Their Social Determinants: An Analysis over Developed vs. Developing EU Member States

Western European countries, except Portugal. Even though Portugal is considered a developed country by several international organisations, just for this study, and in accordance with the conditions imposed by the methodology we use, we included it in the group of developing countries, as the value of its GDP per capita in PPS is lower than the median value of the EU Member States for 2017.

As we mentioned in the methodology, we estimated the impact of the exogenous variables on the Gini coefficient in the case of each cluster. However, given the fact that all variables proved to be stationary at the first difference, first, we reviewed the results of five tests ${ }^{1}$ to decide the appropriate lag of both models. In this context, Table 1 shows that one lag fits best to both models, this being selected by all tests used, compared with zero lag, which was not considered appropriate by the lag length criteria method. Furthermore, we checked the compatibility with a Fixed Effects Model (Table 2) using Redundant Fixed Effects Test, which demonstrated that using this method is the most appropriate way forward to obtain robust and accurate coefficients, without being affected by the heterogeneity issues, since its probability is lower than 5\% in the case of both models (clusters).

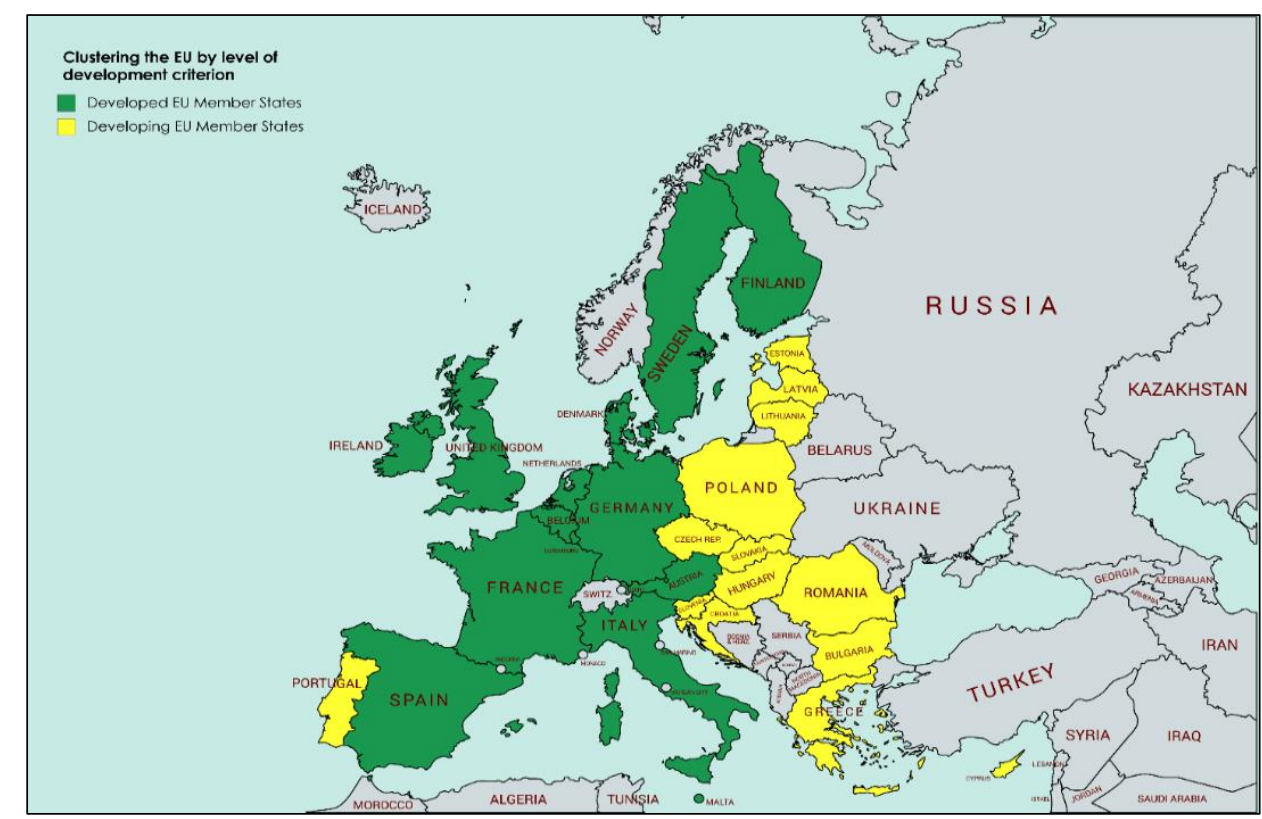

Figure 1. Clustering the $\mathbf{E U}$ by level of development criterion

Source: Own processing on mapchart.net, using Eurostat data - GDP per capita expressed in purchasing power standard (PPS)

\footnotetext{
${ }^{1}$ Sequential Modified LR test statistic, Final prediction error, Akaike information criterion, Schwarz information
} criterion and Hannan-Quinn information criterion. 
Ionuț Jianu, Ioana Andrada Gavril, Silvia Elena Iacob, Andrei Hrebenciuc

Following the estimation of the models, we obtained robust and significant coefficients, since their specific probabilities are lower than 5\%. In addition, the standard errors are not zero, but close to it, which also indicates the accuracy of the estimators. The selected independent variables were representative for the dependent variables, this being also confirmed by the high values of R-squared. For instance, in the case of the developed EU Member States model, the variables we have used explain $98.51 \%$ of the evolution of the Gini coefficient, while the same variables used in the case of the developing EU Member States model explain $98.63 \%$ of the dependent variable development. The high values of R-squared confirmed the absence of multicollinearity in both cases, since these are higher than the Pearson correlation between the independent variables. However, we also bear in mind the fact that the high R-squared values is a specificity of the Fixed Effects Model. In this regard, we advanced our work by checking the other hypotheses of Gauss Markov theorem, but first we analysed the relationships between exogenous and dependent variables.

Table 1. Lag selection

\begin{tabular}{l|cc}
\hline \multirow{2}{*}{ Lag information criterion } & \multicolumn{2}{|c}{ Lag checked } \\
\cline { 2 - 3 } & 0 & $\mathbf{1}$ \\
\hline Sequential modified LR test statistic & NA & $1184.052^{*}$ \\
\hline Final prediction error & 61438.27 & $0.251813^{*}$ \\
\hline Akaike information criterion & 22.37729 & $9.972084^{*}$ \\
\hline Schwarz information criterion & 22.48280 & $10.49963^{*}$ \\
\hline Hannah-Quinn information criterion & 22.41997 & $10.18547^{*}$ \\
\hline
\end{tabular}

Note: *lag selected

Source: Own calculations using Eviews 9.0

Table 2. Checking the compatibility with the Fixed Effects Model

\begin{tabular}{l|cc}
\hline Test & $\begin{array}{c}\text { Developed EU Member } \\
\text { States model }\end{array}$ & $\begin{array}{c}\text { Developing EU Member } \\
\text { States model }\end{array}$ \\
\hline Redundant Fixed Effect test & $0.0000(\mathrm{p}<.05)$ & $0.0000(\mathrm{p}<.05)$ \\
\hline
\end{tabular}

Source: Own calculations using Eviews 9.0

\section{1. Income Inequality and Historical Income Inequality}

Regarding the relationship between income inequality and its historical evolution, we proved that (Table 3) an increase in the Gini coefficient lagged by one year with 1 deviation point in the developed EU MS model led to a hike of the actual Gini coefficient with 0.30 deviation points, which also proves the capacity of higher incomes to generate another type of incomes. The computed impact is lower than the one obtained in the case of the developing EU MS model ( 0.44 deviation points).

Our finding can be explained by a vicious circle that may be described as follows: in developing economies, poorer social and economic conditions (such as the quality of education, lower social spending, labour market inflexibilities and 
Income Inequalities and Their Social Determinants: An Analysis over Developed vs. Developing EU Member States

others) determine poorer chances for development, which in turn undermines the chances of the poor for escaping their condition. The positive relationship between present and past income inequality is also valid for developed countries of the EU, but the link is weaker, as the poor population in these countries have more opportunities to migrate to richer quintiles, since they have access to better education, possibly better conditions on the labour market and so on. Moreover, the low income in developing countries may undermine acces to education and other opportunities, while high income for the top deciles allow for better education, which leads to a greater income dispersion.

Table 3. Estimation results: 2010-2017

\begin{tabular}{l|cc}
\hline \multirow{2}{*}{ Variables } & $\begin{array}{c}\text { Developed EU Member } \\
\text { States model }\end{array}$ & $\begin{array}{c}\text { Developing EU Member } \\
\text { States model }\end{array}$ \\
\cline { 2 - 3 } & Coefficient / Std. Error & Coefficient / Std. Error \\
\hline \multirow{2}{*}{ Gini(-1) } & $0.305^{*}$ & $0.448^{*}$ \\
& $(0.114)$ & $-0.158^{* *}$ \\
\hline \multirow{2}{*}{ social(-1) } & $-0.196^{*}$ & $(0.069)$ \\
\hline \multirow{2}{*}{ tertattaint(-1) } & $(0.034)$ & $-0.081^{*}$ \\
\hline \multirow{2}{*}{ unem(-1) } & $0.041^{*}$ & $(0.026)$ \\
\hline \multirow{2}{*}{ Constant } & $(0.014)$ & $0.034^{* *}$ \\
& $0.079^{*}$ & $(0.016)$ \\
\hline R-squared & $(0.026)$ & $21.061^{*}$ \\
\hline Prob(F-statistic) & $21.987^{*}$ & $(1.699)$ \\
\hline Observations & $(3.467)$ & 0.9863 \\
\hline
\end{tabular}

Note: *significant at 1\%, **significant at 5\%; standard errors in parentheses. Source: Own calculations using Eviews 9.0

\section{2. Income Inequality and Social Protection Spending}

With a view to the relationship between income inequality and government spending on social protection, according to our results, an increase by 1 percentage point in the share of government spending on social protection to GDP, lagged by one year, led to a drop of the actual Gini coefficient with 0.19 deviation points in the developed EU MS (compared to 0.15 deviation points for developing countries). Our findings are similar to the ones presented in the literature, which show a negative relationship between income inequality and social expenditure. However, we find that this negative relationship is a bit stronger in developed countries compared to the developing ones. One possible reason for this might be the fact that in developed countries social benefits systems are better designed and means tested benefits are more effective, which in turn determines a better social and economic inclusion for the poorer deciles of the population (through better education and labour market participation), leading to lower inequalities. 
Ionuț Jianu, Ioana Andrada Gavril, Silvia Elena Iacob, Andrei Hrebenciuc

\section{3. Income Inequality and Tertiary Educational Attainment}

As we stated before, tertiary educational attainment rate also represents a factor that influences income inequality, since better skilled persons will earn more. Our econometric modelling supports this assumption, but the impact we found is rather weak. Moreover, our results lead to different conclusions regarding the impact of tertiary education on income inequality in developing versus developed EU Member States. In the developing countries, an increase with 1 percentage point of the tertiary educational attainment rate lagged by one year generates a reduction of the Gini coefficient by 0.08 deviation points. However, in the case of the developed EU MS, we found a positive relationship between the mentioned variables. According to Table 3, an increase in the tertiary educational attainment rate lagged by one year caused a growth of the dependent variable with 0.04 deviation points. This might be explained by the fact that the access to tertiary education may be granted for different social categories in developing versus developed countries. In developing countries, the costs of tertiary education are much lower than in developed ones and therefore this may give access to youth in low and medium income deciles to the educational systems, creating the opportunity for intergenerational mobility and increased income. In this way, inequalities are likely to decrease. On the other hand, in developed countries, where skilled labour is better payed than in developing ones, the tertiary attainment is likely to generate an increase in income at the top of the income distribution, so that this might explain our positive effect of tertiary attainment on income inequality.

\section{4. Income Inequality and Unemployment}

Another important factor of income inequality according to the scientific economic literature is unemployment rate. Our econometric modelling also supports this view, both for developing and developed countries. According to our estimation, an increase in the unemployment rate lagged by one year in 2010-2017 period generated a hike in the Gini coefficient with 0.07 deviation points in the case of the developed EU MS model, which is higher than the effect we found for the developing EU MS (0.03 deviation points). This can be argued by the fact that unemployment affects, to a greater extent, the active population in low-income social classes, leading to an increase of income inequality. However, the effect is stronger in EU developed countries, since the crisis affected the will of the population from developing EU Member States to search for jobs, which underestimated the unemployment rate calculation.

\section{5. Other Model Hypotheses}

We confirmed the maximum verosimility of the models since both equation residuals respected the hypotheses of Gauss-Markov. In this respect, 
Income Inequalities and Their Social Determinants: An Analysis over Developed vs. Developing EU Member States

Jarque-Bera probabilities ${ }^{2}$ demonstrated that the residuals are normally distributed, while the Cross-section dependence test (composed by: Breusch-Pagan LM, Pesaran scaled LM, Bias-corrected scaled LM and Pesaran CD) has provided appropriate results which argued the absence of cross-section dependence (Annex 1). In the case of the Developed EU MS model, all tests used confirmed its absence (null). However, in the case of Developing EU MS model, 2 of 4 tests confirmed the null hypothesis, but one of the others is close to $5 \%$. This determined us to accept the model in this form taking into account the appropriate results of all checked hypotheses.

In Annex 1 we have provided the results of the heteroskedasticity and autocorrelation of the residuals tests. Our results confirmed the absence of heteroskedasticity, which is in line with the requirements of the Gauss-Markov theorem to validate the maximum verisimilitude of the coefficients, since BreuschPagan-Godfrey test provides a probability higher than $5 \%$ in the case of both models (94.93\% - Developed EU MS model; 26.60\% - Developing EU MS model). On the other hand, the absence of autocorrelation between residuals was confirmed by the Breusch-Pagan test, which has provided a probability higher than the threshold of 5\% for each model (51.35\% - Developed EU MS model; 23.04\% Developing EU MS model). Following the validation of the checked hypotheses, we confirmed the maximum verosimility of the obtained coefficients.

Regarding the robustness testing, in Annex 2 and Annex 3, we have briefly provided the results of the 44 additional estimated models (full versions of the results can be provided at request). Generally, the results are close to the ones of the baseline model when excluding one year / country. There is only one exception, which is related to the exclusion of the year 2016 from the developing EU MS model. When performing this structural change, the sign of the tertiary educational attainment rate coefficient became slightly positive. However, this will not raise any issue related to uncertainty since three of the coefficients are insignificant (including the one mentioned above) at a significance threshold of 5\%.

\section{Conclusions and recommendations}

Generally, our results confirm the findings of the literature in this field. We have concluded that the relationship between the historical income inequality and its current dimensions is stronger in EU developing countries than in developed ones, which proves that the effectiveness of the social inclusion reforms is smaller in the former ones, as a consequence of the historical inequality positive effect on its current dimension. Developing EU countries might find themselves in a vicious circle we described in our introduction: higher income inequality and poverty hinders social and economic conditions for low income deciles, which in turn determines the inequality to rise. Moreover, for low income families, limited access

\footnotetext{
${ }^{2}$ In the case of the Developed EU MS model, Jarque-Bera probability is $11.29 \%$, while the probability specific to the Developing EU MS model is $54.81 \%$, both being higher than $5 \%$ - the condition to confirm the normal distribution of the residuals.
} 
Ionuț Jianu, Ioana Andrada Gavril, Silvia Elena Iacob, Andrei Hrebenciuc

to education alongside with inequality of opportunity, undermines intergenerational mobility, which means that youth in poor families will remain poor as adults.

We also found a higher capacity of government spending on social protection to reduce income inequality in the case of developed Member States. We explain this by the fact that in developed countries social benefits systems are better designed and means tested benefits are more effective, which in turn determines a better social and economic inclusion for the poorer deciles of the population, leading to lower inequalities.

In addition, we identified a positive relationship between tertiary education attainment in the developed EU countries and a negative one in the case of developing EU Member States. We explain this finding by the fact that in developing countries access to tertiary education is cheaper and it might be granted more easily to youth in low and medium income deciles, creating some opportunity for intergenerational mobility and increased income. On the other hand, in developed countries, where skilled labour is better payed than in developing ones, the tertiary attainment is likely to generate an increase in income gap.

Our analysis proves a positive relationship between unemployment and income inequality in both clusters, similar to other results within the literature. This can be argued by the fact that unemployment affects, to a greater extent, the active population in low-income social classes, leading to an increase of income inequality. However, the effect is stronger in EU developed countries, since the crisis affected the will of the population living in developing EU Member States to search for jobs, which underestimated the unemployment rate calculation.

The determinants of income inequality should be carefully assessed in every country and governments should try to moderate its excessive levels, as it has a negative social and economic impact. Income inequality can only be addressed at the governmental level, by effective and inclusive public policies, such as: higher progressivity of taxes, certain means tested benefits and transfers (including in kind social transfers for education and health), inclusive and better educational systems or certain labour market policies (e.g. minimum wages), better designed institutions and so on. However, the way the government intervenes needs to be in line with the cultural, social, economic and fiscal features, so that public policies prove to be efficient in diminishing excessive levels of income inequality.

\section{REFERENCES}

[1] Aghion, P., Akcigit, U., Bergeaud, A., Blundell, R. and Hemous, D. (2019), Innovation and Top Income Inequality. The Review of Economic Studies, Vol. 86, No. 1, pp. 1-45;

[2] Aiyar, S. and Ebeke, C. (2019), Inequality of Opportunity, Inequality of Income and Economic Growth. IMF Working Paper, WP/19/34; 
Income Inequalities and Their Social Determinants: An Analysis over Developed vs. Developing EU Member States

[3] Ayad, H., Sari Hassoun, S.E., Mostefa, B. (2020), Causality between Government Expenditure and Economic Growth in Algeria: Explosive Behaviour Tests and Frequency Domain Spectral Causality. Economic Computation and Economic Cybernetics Studies and Research, Issue 2/2020;

[4] Cornia, G. A. (2015), Income Inequality in Latin America: Recent Decline and Prospects for its Further Reduction. WIDER Working Paper Series 020, World Institute for Development Economic Research (UNU-WIDER);

[5] Cruces, G., Domench, G. C. and Gasparini, L. (2012), Inequality in Education: Evidence for Latin America. Centro de Estudios Distributivos, Laborales y Sociales Documento de Trabajo, No. 135;

[6] Dabla-Norris, E., Kochhar, K., Ricka, F., Suphaphiphat, N. and Tsounta, E. (2015), Causes and Consequences of Income Inequality: A Global Perspective. IMF Staff Discussion Note;

[7] De Gregorio, J. and Lee, J. W. (2002), Education and Income Distribution: New Evidence from Cross-Country Data. Review of Income and Wealth, Vol. 48, No. 3, pp. 395-416;

[8] Dobre, I., Jianu, I., Bodislav, D.A., Rădulescu, C.V., Burlacu, S. (2019), The Implications of Institutional Specificities on the Income Inequalities Drivers in the European Union. Economic Computation and Economic Cybernetics Studies and Research, Issue 2/2019, Vol. 53; ASE Publishing;

[9] Eurostat (2019), Eurostat Database, [online];

[10] Galbraith, J. K., Conceicao, P. and Ferreira, P. A. (2000), Inequality and Unemployment in Europe: The American Cure. UTIP Working Paper, No. 11; [11] Galor, O. and Moav, O. (2004), From Physical to Human Capital Accumulation: Inequality and the Process of Development. Review of Economic Studies, Vol. 71, No. 4, pp. 1001-1026;

[12] Istudor, N., Dinu, V., Gogu, E., Prada, E.-M. \& Petrescu, I.-E. (2020), Impact of Education and Economic Growth on Labour Migration in the European Union. A Panel Data Analysis. E\&M Economics and Management, 23(4), 55-67;

[13] Jaumotte, F., Lall, S. and Papageorgiou, C. (2013), Rising Income Inequality: Technology, or Trade and Financial Globalization?; IMF Economic Review, Vol. 61, No. 2, pp. 271-309;

[14] Josifidis, K., Supić, N., Beker Pucar, E. (2017), Institutional Quality and Income Inequality in the Advanced Countries. Panoeconomicus, Vol. 64, No. 2 Special Issue, pp. 169-188.;

[15] Matos, C. (2019), Inequality and Crisis: Conspicuous Consumption as the Missing Link in the Portuguese Case. Journal of Economic Issues, Vol. 53, No. 1, pp. 26-38;

[16] Mehic, A. (2018), Industrial Employment and Income Inequality: Evidence from Panel Data. Structural Change and Economic Dynamics, Vol. 45, pp. 84-93; [17] Mocan, N. (1995), Structural Unemployment, Cyclical Unemployment, and Income Inequality. The Review of Economics and Statistics, Vol. 81, No. 1, pp. 122-134; 
Ionuț Jianu, Ioana Andrada Gavril, Silvia Elena Iacob, Andrei Hrebenciuc

[18] Molina-Morales, A., Amate-Fortes, I. and Guarnido-Rueda, A. (2013), Social Expenditure in the European Union: Does Inequality Matter?; Journal of Economic Issues, Vol. 47, No. 3, pp. 745-764;

[19] Niehues, J. (2010), Social Spending Generosity and Income Inequality: A Dynamic Panel Approach. IZA Discussion Paper, No. 5178;

[20] Partridge, M. D., Rickman, D. S. and Levernier, W. (1996), Trends in US Income Inequality:Evidence from a Panel of States. The Quarterly Review of Economics and Finance, Vol. 36, No. 1, pp. 17-37;

[21] Røed, K. and Strøm, S. (2002), Progressive Taxes and the Labour Market: Is the Trade-Off between Equality and Efficiency Inevitable?; Journal of Economic Surveys, Vol. 16, No. 1, pp. 77-110;

[22] Sen, A. (1997), Inequality, Unemployment and Contemporary Europe. International Labour Review, Vol. 136, No. 2, pp. 155-171;

[24] Stiglitz, J. E. (2012), The Price of Inequality: How Today`s Divided Society Endangers Our Future; New York: W. W. Norton \& Co.;

[24] Walker, J., Pearce, C., Boe, K. and Lawson, M. (2019), The Power of Education to Fight Inequality: How Increasing Educational Equality and Quality is Crucial to Fighting Economic and Gender Inequality. Oxfam briefing Paper.

\section{Annexes}

Annex 1. Testing the residuals II

Cross-section dependence test

\begin{tabular}{l|cc}
\hline Test & $\begin{array}{c}\text { Developed EU Member States } \\
\text { model (p) }\end{array}$ & $\begin{array}{c}\text { Developing EU Member } \\
\text { States model (p) }\end{array}$ \\
\hline Breusch-Pagan LM & $0.1574(\mathrm{p}>.05)$ & $0.0422(\mathrm{p}<.05)$ \\
\hline Pesaran scaled LM & $0.9716(\mathrm{p}>.05)$ & $0.4345(\mathrm{p}>.05)$ \\
\hline Bias-corrected scaled LM & $0.2293(\mathrm{p}>.05)$ & $0.7002(\mathrm{p}>.05)$ \\
\hline Pesaran CD & $0.8447(\mathrm{p}>.05)$ & $0.0017(\mathrm{p}<.05)$ \\
\hline
\end{tabular}

Source: Own calculations using Eviews 9.0

Heteroskedasticity test - Breusch-Pagan-Godfrey

\begin{tabular}{l|cc}
\hline Heteroskedasticity test & $\begin{array}{c}\text { Developed EU Member States } \\
\text { model }\end{array}$ & $\begin{array}{c}\text { Developing EU Member } \\
\text { States model }\end{array}$ \\
\hline $\begin{array}{l}\text { R-squared (dependent variable: } \\
\text { resid01^2) }\end{array}$ & 0.007312 & 0.053205 \\
\hline Observations (n) & 98 & 98 \\
\hline $\mathrm{n} *$ R-squared & 0.716576 & 5.21409 \\
\hline Degrees of freedom & 4 & 4 \\
\hline Prob. Breusch-Pagan-Godfrey & $\begin{array}{c}0.94926914 \\
(\mathrm{p}>.05)\end{array}$ & $\begin{array}{c}0.266027359 \\
(\mathrm{p}>.05)\end{array}$ \\
\hline
\end{tabular}

Source: Own calculations using Eviews 9.0 and Microsoft Office Excel 2016 
Income Inequalities and Their Social Determinants: An Analysis over Developed vs. Developing EU Member States

\section{Autocorrelation of the residuals test - Breusch-Pagan}

\begin{tabular}{l|cc}
\hline Autocorrelation test & $\begin{array}{c}\text { Developed EU Member States } \\
\text { model }\end{array}$ & $\begin{array}{c}\text { Developing EU Member } \\
\text { States model }\end{array}$ \\
\hline $\begin{array}{l}\text { R-squared (dependent variable: } \\
\text { resid01) }\end{array}$ & 0.005082 & 0.017122 \\
\hline Observations (n) & 84 & 84 \\
\hline $\mathrm{n}$ R-squared & 0.426888 & 1.438248 \\
\hline Degrees of freedom & 1 & 1 \\
\hline Prob. Breusch-Pagan & $\begin{array}{c}0.513519923 \\
(\mathrm{p}>.05)\end{array}$ & $\begin{array}{c}0.230423063 \\
(\mathrm{p}>.05)\end{array}$ \\
\hline
\end{tabular}

Source: Own calculations using Eviews 9.0 and Microsoft Office Excel 2016

Annex 2. Robustness check (excluding one year, dependent: Gini)

\begin{tabular}{|c|c|c|c|c|c|}
\hline \multirow{2}{*}{$\begin{array}{c}\text { Year } \\
\text { excluded }\end{array}$} & \multicolumn{5}{|c|}{ Variables } \\
\hline & Gini(-1) & social(-1) & tertattaint $(-1)$ & unem(-1) & R-squared \\
\hline \multicolumn{6}{|c|}{ Developed EU Member States model } \\
\hline 2010 & $\begin{array}{l}0.368^{*} \\
(0.155) \\
\end{array}$ & $\begin{array}{l}-0.154^{*} \\
(0.060) \\
\end{array}$ & $\begin{array}{c}0.031 \\
(0.018) \\
\end{array}$ & $\begin{array}{l}0.087 * \\
(0.037)\end{array}$ & 0.985 \\
\hline 2011 & $\begin{array}{c}0.176 \\
(0.119) \\
\end{array}$ & $\begin{array}{c}-0.145 \\
(0.095) \\
\end{array}$ & $\begin{array}{c}0.034 \\
(0.023) \\
\end{array}$ & $\begin{array}{l}0.106^{*} \\
(0.050)\end{array}$ & 0.987 \\
\hline 2012 & $\begin{array}{l}0.331^{*} \\
(0.061)\end{array}$ & $\begin{array}{l}-0.269^{*} \\
(0.030) \\
\end{array}$ & $\begin{array}{l}0.042 * \\
(0.018)\end{array}$ & $\begin{array}{l}0.155^{*} \\
(0.016)\end{array}$ & 0.994 \\
\hline 2013 & $\begin{array}{l}0.523^{*} \\
(0.104)\end{array}$ & $\begin{array}{l}-0.233^{*} \\
(0.046)\end{array}$ & $\begin{array}{l}0.036^{*} \\
(0.012)\end{array}$ & $\begin{array}{l}0.074^{*} \\
(0.030)\end{array}$ & 0.992 \\
\hline 2014 & $\begin{array}{l}0.547^{*} \\
(0.134)\end{array}$ & $\begin{array}{l}-0.137^{*} \\
(0.054)\end{array}$ & $\begin{array}{l}0.066^{*} \\
(0.012)\end{array}$ & $\begin{array}{c}0.018 \\
(0.020)\end{array}$ & 0.983 \\
\hline 2015 & $\begin{array}{c}0.274 \\
(0.185)\end{array}$ & $\begin{array}{l}-0.163^{*} \\
(0.044)\end{array}$ & $\begin{array}{l}0.064^{*} \\
(0.018)\end{array}$ & $\begin{array}{l}0.052^{*} \\
(0.007)\end{array}$ & 0.984 \\
\hline 2016 & $\begin{array}{c}0.066 \\
(0.117)\end{array}$ & $\begin{array}{l}-0.223^{*} \\
(0.026)\end{array}$ & $\begin{array}{c}0.024 \\
(0.024)\end{array}$ & $\begin{array}{l}0.058^{*} \\
(0.009)\end{array}$ & 0.989 \\
\hline 2017 & $\begin{array}{c}0.247 \\
(0.155) \\
\end{array}$ & $\begin{array}{l}-0.170 * \\
(0.043) \\
\end{array}$ & $\begin{array}{c}0.027) \\
(0.015) \\
\end{array}$ & $\begin{array}{l}0.082 * \\
(0.020)\end{array}$ & 0.984 \\
\hline \multicolumn{6}{|c|}{ Developing EU Member States model } \\
\hline 2010 & $\begin{array}{l}0.439^{*} \\
(0.126) \\
\end{array}$ & $\begin{array}{c}-0.092 \\
(0.108) \\
\end{array}$ & $\begin{array}{l}-0.112^{*} \\
(0.022) \\
\end{array}$ & $\begin{array}{c}0.023 \\
(0.028) \\
\end{array}$ & 0.987 \\
\hline 2011 & $\begin{array}{l}0.346^{*} \\
(0.155)\end{array}$ & $\begin{array}{l}-0.063 \\
(0.124)\end{array}$ & $\begin{array}{l}-0.117^{*} \\
(0.022)\end{array}$ & $\begin{array}{c}0.064 \\
(0.049)\end{array}$ & 0.989 \\
\hline 2012 & $\begin{array}{l}0.378^{*} \\
(0.114)\end{array}$ & $\begin{array}{l}-0.425^{*} \\
(0.077)\end{array}$ & $\begin{array}{l}-0.073^{*} \\
(0.022) \\
\end{array}$ & $\begin{array}{l}0.085^{*} \\
(0.036) \\
\end{array}$ & 0.985 \\
\hline 2013 & $\begin{array}{l}0.528^{*} \\
(0.039)\end{array}$ & $\begin{array}{l}-0.245^{*} \\
(0.062)\end{array}$ & $\begin{array}{l}-0.085^{*} \\
(0.020)\end{array}$ & $\begin{array}{l}0.047^{*} \\
(0.016)\end{array}$ & 0.991 \\
\hline 2014 & $\begin{array}{l}0.429^{*} \\
(0.043)\end{array}$ & $\begin{array}{l}-0.165^{*} \\
(0.066)\end{array}$ & $\begin{array}{l}-0.095^{*} \\
(0.021)\end{array}$ & $\begin{array}{l}0.032^{*} \\
(0.014)\end{array}$ & 0.991 \\
\hline 2015 & $\begin{array}{l}0.000^{*} \\
(0.057)\end{array}$ & $\begin{array}{l}-0.137 \\
(0.072)\end{array}$ & $\begin{array}{l}-0.091^{*} \\
(0.038)\end{array}$ & $\begin{array}{c}0.012 \\
(0.009)\end{array}$ & 0.983 \\
\hline 2016 & $\begin{array}{l}0.378^{*} \\
(0.030)\end{array}$ & $\begin{array}{c}-0.132 \\
(0.111)\end{array}$ & $\begin{array}{c}0.052 \\
(0.049)\end{array}$ & $\begin{array}{c}0.005 \\
(0.027)\end{array}$ & 0.985 \\
\hline 2017 & $\begin{array}{l}0.360^{*} \\
(0.036)\end{array}$ & $\begin{array}{l}-0.135 \\
(0.078)\end{array}$ & $\begin{array}{l}-0.016 \\
(0.028)\end{array}$ & $\begin{array}{c}0.031 \\
(0.020)\end{array}$ & 0.988 \\
\hline
\end{tabular}

*significant at 5\%; standard errors in parentheses.

Source: Own calculations using Eviews 9.0 
Ionuț Jianu, Ioana Andrada Gavril, Silvia Elena Iacob, Andrei Hrebenciuc

\section{Annex 3. Robustness check (excluding one country, dependent: Gini)}

\begin{tabular}{|c|c|c|c|c|c|}
\hline \multirow{2}{*}{$\begin{array}{r}\text { Country } \\
\text { excluded }\end{array}$} & \multicolumn{5}{|c|}{ Variables } \\
\hline & Gini(-1) & social(-1) & tertattaint $(-1)$ & unem(-1) & R-squared \\
\hline \multicolumn{6}{|c|}{ Developing EU Member States model } \\
\hline BG & $\begin{array}{l}0.389 * \\
(0.049) \\
\end{array}$ & $\begin{array}{l}-0.222 * \\
(0.071) \\
\end{array}$ & $\begin{array}{l}-0.084 * \\
(0.025) \\
\end{array}$ & $\begin{array}{l}0.051^{*} \\
(0.019)\end{array}$ & 0.987 \\
\hline $\mathrm{CZ}$ & $\begin{array}{l}0.461 * \\
(0.056) \\
\end{array}$ & $\begin{array}{l}-0.165^{*} \\
(0.070)\end{array}$ & $\begin{array}{l}-0.086^{*} \\
(0.028)\end{array}$ & $\begin{array}{c}0.032 \\
(0.017)\end{array}$ & 0.978 \\
\hline EE & $\begin{array}{c}0.453 * \\
(0.054)\end{array}$ & $\begin{array}{l}-0.103 \\
(0.077)\end{array}$ & $\begin{array}{c}-0.079^{*} \\
(0.026)\end{array}$ & $\begin{array}{c}0.026 \\
(0.014)\end{array}$ & 0.987 \\
\hline EL & $\begin{array}{l}0.444 * \\
(0.062)\end{array}$ & $\begin{array}{l}-0.208^{*} \\
(0.084)\end{array}$ & $\begin{array}{l}-0.069^{*} \\
(0.020)\end{array}$ & $\begin{array}{l}0.052 * \\
(0.025)\end{array}$ & 0.985 \\
\hline HR & $\begin{array}{l}0.410^{*} \\
(0.085) \\
\end{array}$ & $\begin{array}{c}-0.189^{*} \\
(0.083) \\
\end{array}$ & $\begin{array}{c}-0.067 \\
(0.035) \\
\end{array}$ & $\begin{array}{c}0.051 \\
(0.026) \\
\end{array}$ & 0.986 \\
\hline CY & $\begin{array}{l}0.447 * \\
(0.054) \\
\end{array}$ & $\begin{array}{l}-0.141 \\
(0.071) \\
\end{array}$ & $\begin{array}{l}-0.086^{*} \\
(0.024) \\
\end{array}$ & $\begin{array}{c}0.024 \\
(0.015) \\
\end{array}$ & 0.987 \\
\hline LV & $\begin{array}{l}0.488 * \\
(0.061) \\
\end{array}$ & $\begin{array}{l}-0.089 \\
(0.062) \\
\end{array}$ & $\begin{array}{l}-0.086^{*} \\
(0.026) \\
\end{array}$ & $\begin{array}{c}0.030 \\
(0.018) \\
\end{array}$ & 0.984 \\
\hline LT & $\begin{array}{l}0.443^{*} \\
(0.043) \\
\end{array}$ & $\begin{array}{l}-0.103 \\
(0.065) \\
\end{array}$ & $\begin{array}{l}-0.087^{*} \\
(0.020)\end{array}$ & $\begin{array}{l}0.041 * \\
(0.015)\end{array}$ & 0.990 \\
\hline $\mathrm{HU}$ & $\begin{array}{l}0.506^{*} \\
(0.093) \\
\end{array}$ & $\begin{array}{c}-0.189^{*} \\
(0.080) \\
\end{array}$ & $\begin{array}{l}-0.081^{*} \\
(0.026) \\
\end{array}$ & $\begin{array}{c}0.029 \\
(0.017) \\
\end{array}$ & 0.984 \\
\hline PL & $\begin{array}{c}0.433 * \\
(0.056) \\
\end{array}$ & $\begin{array}{l}-0.128 \\
(0.085)\end{array}$ & $\begin{array}{l}-0.070^{*} \\
(0.030)\end{array}$ & $\begin{array}{c}0.025 \\
(0.017) \\
\end{array}$ & 0.986 \\
\hline PT & $\begin{array}{l}0.438 * \\
(0.054) \\
\end{array}$ & $\begin{array}{l}-0.212^{*} \\
(0.088)\end{array}$ & $\begin{array}{l}-0.087^{*} \\
(0.030) \\
\end{array}$ & $\begin{array}{c}0.036 \\
(0.019) \\
\end{array}$ & 0.983 \\
\hline RO & $\begin{array}{l}0.469 * \\
(0.051) \\
\end{array}$ & $\begin{array}{l}-0.148^{*} \\
(0.068)\end{array}$ & $\begin{array}{l}-0.082^{*} \\
(0.024)\end{array}$ & $\begin{array}{c}0.030 \\
(0.015)\end{array}$ & 0.986 \\
\hline SI & $\begin{array}{l}0.446^{*} \\
(0.058) \\
\end{array}$ & $\begin{array}{l}-0.192^{*} \\
(0.066)\end{array}$ & $\begin{array}{l}-0.083^{*} \\
(0.024)\end{array}$ & $\begin{array}{c}0.035 \\
(0.019) \\
\end{array}$ & 0.982 \\
\hline SK & $\begin{array}{l}0.475^{*} \\
(0.048)\end{array}$ & $\begin{array}{l}-0.144^{*} \\
(0.070)\end{array}$ & $\begin{array}{l}-0.081^{*} \\
(0.026)\end{array}$ & $\begin{array}{c}0.028 \\
(0.016)\end{array}$ & 0.986 \\
\hline \multicolumn{6}{|c|}{ Developed EU Member States model } \\
\hline $\mathrm{BE}$ & $\begin{array}{l}0.329 * \\
(0.118) \\
\end{array}$ & $\begin{array}{l}-0.188 * \\
(0.044) \\
\end{array}$ & $\begin{array}{l}0.043 * \\
(0.015)\end{array}$ & $\begin{array}{l}0.077 * \\
(0.029)\end{array}$ & 0.984 \\
\hline DK & $\begin{array}{l}0.287^{*} \\
(0.110)\end{array}$ & $\begin{array}{l}-0.188^{*} \\
(0.035)\end{array}$ & $\begin{array}{l}0.034 * \\
(0.016)\end{array}$ & $\begin{array}{l}0.084 * \\
(0.025)\end{array}$ & 0.986 \\
\hline $\mathrm{DE}$ & $\begin{array}{l}0.294 * \\
(0.117)\end{array}$ & $\begin{array}{l}-0.196^{*} \\
(0.010)\end{array}$ & $\begin{array}{c}0.0387^{*} \\
(0.014)\end{array}$ & $\begin{array}{l}0.083^{*} \\
(0.025)\end{array}$ & 0.986 \\
\hline IE & $\begin{array}{l}0.259^{*} \\
(0.114)\end{array}$ & $\begin{array}{l}-0.263^{*} \\
(0.016)\end{array}$ & $\begin{array}{l}0.056^{*} \\
(0.014)\end{array}$ & $\begin{array}{l}0.069 * \\
(0.028)\end{array}$ & 0.986 \\
\hline ES & $\begin{array}{l}0.335^{*} \\
(0.115)\end{array}$ & $\begin{array}{l}-0.185^{*} \\
(0.032)\end{array}$ & $\begin{array}{l}0.042^{*} \\
(0.014)\end{array}$ & $\begin{array}{c}0.065 \\
(0.042)\end{array}$ & 0.975 \\
\hline FR & $\begin{array}{c}0.283^{*} \\
(0.109)\end{array}$ & $\begin{array}{l}-0.187^{*} \\
(0.036)\end{array}$ & $\begin{array}{l}0.055^{*} \\
(0.014)\end{array}$ & $\begin{array}{l}0.080^{*} \\
(0.027)\end{array}$ & 0.985 \\
\hline IT & $\begin{array}{l}0.350^{*} \\
(0.120) \\
\end{array}$ & $\begin{array}{l}-0.204^{*} \\
(0.034)\end{array}$ & $\begin{array}{l}0.041 * \\
(0.016)\end{array}$ & $\begin{array}{l}0.100 * \\
(0.037)\end{array}$ & 0.980 \\
\hline LU & $\begin{array}{l}0.302 * \\
(0.110) \\
\end{array}$ & $\begin{array}{c}-0.189^{*} \\
(0.036) \\
\end{array}$ & $\begin{array}{l}0.040^{*} \\
(0.014)\end{array}$ & $\begin{array}{l}0.071 * \\
(0.025) \\
\end{array}$ & 0.985 \\
\hline MT & $\begin{array}{l}0.346^{*} \\
(0.112) \\
\end{array}$ & $\begin{array}{l}-0.188^{*} \\
(0.039) \\
\end{array}$ & $\begin{array}{c}0.030 \\
(0.019) \\
\end{array}$ & $\begin{array}{l}0.084 * \\
(0.024) \\
\end{array}$ & 0.985 \\
\hline NL & $\begin{array}{l}0.259^{*} \\
(0.112) \\
\end{array}$ & $\begin{array}{l}-0.176^{*} \\
(0.040)\end{array}$ & $\begin{array}{l}0.036^{*} \\
(0.014)\end{array}$ & $\begin{array}{l}0.057 * \\
(0.026)\end{array}$ & 0.985 \\
\hline AT & $\begin{array}{l}0.302 * \\
(0.114) \\
\end{array}$ & $\begin{array}{l}-0.193^{*} \\
(0.037) \\
\end{array}$ & $\begin{array}{l}0.089^{*} \\
(0.018)\end{array}$ & $\begin{array}{l}0.078^{*} \\
(0.030)\end{array}$ & 0.984 \\
\hline FI & $\begin{array}{l}0.338^{*} \\
(0.111) \\
\end{array}$ & $\begin{array}{l}-0.128^{*} \\
(0.059) \\
\end{array}$ & $\begin{array}{l}0.049 * \\
(0.016)\end{array}$ & $\begin{array}{c}0.049 \\
(0.042) \\
\end{array}$ & 0.981 \\
\hline SE & $\begin{array}{l}0.224 * \\
(0.104) \\
\end{array}$ & $\begin{array}{l}-0.216^{*} \\
(0.031) \\
\end{array}$ & $\begin{array}{c}0.024 \\
(0.015) \\
\end{array}$ & $\begin{array}{l}0.099 * \\
(0.023)\end{array}$ & 0.987 \\
\hline UK & $\begin{array}{l}0.318^{*} \\
(0.133)\end{array}$ & $\begin{array}{l}-0.199^{*} \\
(0.034)\end{array}$ & $\begin{array}{l}0.036^{*} \\
(0.016)\end{array}$ & $\begin{array}{l}0.093 * \\
(0.027)\end{array}$ & 0.985 \\
\hline
\end{tabular}

Note: *significant at 5\%; standard errors in parentheses.

Source: Own calculations using Eviews 9.0 